\title{
Changes of tree species diversity in peatland impacted by moderate fire severity at Teluk Meranti, Pelalawan, Riau Province, Indonesia
}

\author{
LAILAN SYAUFINA ${ }^{\vee}$, ANNAS ABI HAMZAH ${ }^{\vee \bullet}$ \\ Department of Silviculture, Faculty of Forestry and Environment, Institut Pertanian Bogor. Jl. Ulin, Lingkar Akademik, Kampus IPB Darmaga, Bogor \\ 16680, West Java, Indonesia. Tel.: +62-251-8626806, Fax. +62-251-8626886, ”email: lailans@ apps.ipb.ac.id, "` annasabihamzah27@gmail.com
}

Manuscript received: 17 March 2021. Revision accepted: 27 April 2021.

\begin{abstract}
Syaufina L, Hamzah AA. 2021. Changes of tree species diversity in peatland impacted by moderate fire severity at Teluk Meranti, Pelalawan, Riau Province, Indonesia. Biodiversitas 22: 2899-2908. Riau is one of the fire-prone provinces in Indonesia, which contributes to environmental problems not only in the country but also in neighboring countries. Peatland fire occurs annually in the province that causes transboundary haze pollution. Despite being an important threat to biodiversity, study on peatland fire impacts seems limited. The aims of this study are to analyze changes in tree species diversity due to fire and to assess fire severity. The study was conducted at Teluk Meranti Sub-district, Pelalawan District, Riau Province, Indonesia by establishing 18 sample plots in six transect lines for both burned and unburned areas. Fire severity classification was assessed by aggregate scoring of vegetation condition (individual tree damages, burned vegetation severity, and biodiversity) and soil condition (physical properties, chemical properties, and burned peat depth) indicators. The research revealed a significant change in tree species diversity from 24 species (unburned area) to 2 species (burned area) from high diversity index (2.86) to low diversity index (0.57); only $29 \%$ of burned trees can survive; average burned peat depth was about $33 \mathrm{~cm}$; a significant difference of soil condition for both areas was observed. The severity of forest fires in Teluk Meranti, Pelalawan, Riau was classified as the moderate category, with a total score of $58.80 \%$.
\end{abstract}

Keywords: diversity index, fire, Indonesia, peatland, severity indicators

\section{INTRODUCTION}

Peatland is a unique ecosystem, which plays a very important role in ecological balance, including hydrological function, carbon stock, and sequestration, biodiversity, and livelihood contributing to Sustainable Development Goals (Page et al. 2011; Harrison 2013; Ishihara et al. 2017; MoEF 2018). It is home to various endemic flora and fauna. An intensive and long-term study in Sebangau National Park-Central Kalimantan, for example, resulted in the list of biodiversity comprising 215 trees, 92 non-tree flora, 73 ants, 66 butterflies, 297 spiders, 41 dragon/damselfly, 55 fish, 11 amphibian, 46 reptile, 172 bird, and 65 mammal taxa. Of these, 46 species are globally threatened, and 59 are currently protected in Indonesia; 22 vertebrate species are Borneo endemics (Husson et al. 2018). Peatland has been an important habitat for various fauna as well, including Sinyulong crocodile (Tomistoma schlegelii), Sumateran tiger (Panthera tigris sumatrae), honey bear (Helarctos malayanus), Tapir (Tapirus indicus), forest duck (Cairina scutulata), and tontong stork (Leptoptilos javanicus), which are among endangered species in Appendix I of CITES and classified as a vulnerable category in the Red Databook of IUCN. Despite biodiversity richness, the peatland area has been under threat from various disturbances, including forest and land fires. It is subjected to much anthropogenic activity, including drainage, logging, agricultural conversion, and burning, resulting in high greenhouse gas and particulate emissions (Lilleskov et al. 2019).
Riau province is a peatland-dominated area in Indonesia that contributes to transboundary haze pollution due to fire, which is closely related to an acute respiratory infection problem experienced by the community in some areas of the province. Peatland fires make a major contribution to atmospheric emissions of greenhouse gases, fine particular matter, and aerosols and thus, contribute to climate change and present a problem for human health (Page et al. 2013; Kiely et al. 2019). Among the areas with the highest hotspot, an indicator of forest and land fire, Bengkalis, Rokan Hilir, and Pelalawan regencies are indicated by clustered hotspot (LAPAN 2016). The fires are caused by burning activities in land preparation for plantation and other purposes, which are triggered by (i) extreme weather, (ii) susceptible peatland characteristics, (iii) uncontrolled fire from land preparation activities, (iv) financial motive of burning activities, (v) lack of field level prevention, (vi) lack of fire suppression, and (vii) weak law enforcement (Mustain 2014).

On the other hand, peatland fire has impacted forest biodiversity as well, which varies from low to high severity (Syaufina and Ainuddin 2011; Lee et al. 2017; Agus et al. 2019) and may lead to deforestation and degradation of carbon-dense tropical peatlands (Hoscilo 2011; Page et al. 2013) and uncertain future status of peatland (Gray 2021). Fire may kill plants and cause injury as direct effect on vegetation. An open wound that attracts pest and disease attack, is indirect effects of fire on vegetation. Fire modify forest structure and composition. The magnitude of fire effects on tropical forest biodiversity is influenced by 
several factors, namely: fire intensity, fire severity, soil types, post-fire precipitation, and burned area (Syaufina and Ainuddin 2011). Studies on fire impacts on biodiversity have been conducted by various approaches, which resulted in various vital information and data (Harrison et al. 2016; Agus et al. 2019). A few of them are published in peer-review journals. Knowledge of key biodiversity-related issues in Southeast Asian tropical peatlands remains fragmentary, from both topical and geographical perspectives (Harrison and Rieley 2018). It seems that there have been a few intensive studies on fire severity and biodiversity in peatland. Therefore, it is necessary to study peatland fire severity related to biodiversity in the context of post-fire rehabilitation and law enforcement related to loss calculation, which is likely to increase in the future.

This study employed a new approach of fire severity assessment using aggregate scoring of two criteria of vegetation condition and soil condition. Each criterion has several indicators and parameters, including individual tree damage, stand damage, burned vegetation severity, and species diversity for vegetation criteria and physical soil properties, chemical soil properties, and burned peat depth for soil criteria. The aims of the study are to (i) analyze tree species diversity changes due to peatland fire and (ii) assess fire severity of peatland fire at Teluk Meranti, Pelalawan District, Riau Province.

\section{MATERIALS AND METHODS}

\section{Study area}

The research was conducted in a 10 ha burned area at Teluk Meranti Sub-district, Pelalawan District, Riau Province (Figure 1). The area was used for field observation and measurements, and Faculty of Forestry IPB, and Faculty of Agriculture IPB were used for laboratory analyses. Teluk Meranti has $423984 \mathrm{Ha}$ area. Geographically, Teluk Meranti Village is located at $0^{0} 10^{\prime}-$ $0^{\circ} 40^{\prime}$ North and $102^{0} 30^{\prime}-102^{\circ} 50^{\prime}$ East, directly adjacent to
Wildlife Sanctuary of Kerumutan and Indragiri Hilir District on the south, with Teluk Binjai Village (west), Pulau Muda Village (east), and Siak District (north) (Rohadi et al. 2018). It is about $190 \mathrm{~km}$ from Pekanbaru, the capital city of Riau, and about $140 \mathrm{~km}$ from Pangkalan Kerinci, the capital city of Pelalawan District.

Pelalawan District is dominated by swampy lowland and peatland areas, ranging from $0-10 \mathrm{~m}$ above sea level. Teluk Meranti is divided by Kampar river flowing down to Malacca strait, where tropical peat swamp forest stretches along both the riversides. It has climate type A (very wet) with an annual rainfall of $2000-3000 \mathrm{~mm}$, a humidity of $81-84 \%$, and an average temperature of $24.5-29.4^{\circ} \mathrm{C}$. The local community of Teluk Meranti is Malay, with livelihoods depending on agriculture, plantation, forestry, fishery, and others.

A fire that occurred in the study area of Teluk Meranti Sub-district on 6 October 2018 was dominated by surface fire, which spread out to ground fire and crown fire as well. It is indicated snags or dead trees without crowns and burned scars in the peat layer. Surface fire is a common type of forest fire, burning surface fuel including forest litter, shrubs, seedlings, and small trees. Fire has been a critical threat to peatland degradation and other environmental impacts (Hoscilo et al. 2011; Turetsky et al. 2015; Page and Hooijer 2016; Isihara et al. 2017). The sampling sites located in $102^{\circ} 35^{\prime} 11.652^{\prime \prime}$ E, $0^{\circ} 7^{\prime} 59.916^{\prime \prime} \mathrm{N}$.

\section{Material and equipment}

Materials used in this study covered vegetation conditions, soil samples, hotspot data, and an administration map of Pelalawan District, Riau Province. Equipment and instruments used in this study included camera, measurement tape, Haga hypsometer, compass, rope, GPS, tally sheet, and plant identification book. This study used software of JASP 0.14.1.0 for analyzing differences between vegetation parameters and soil parameters in burned and unburned plots, using independent t-test for mean values of the parameters, and Google my maps for creating study location maps.

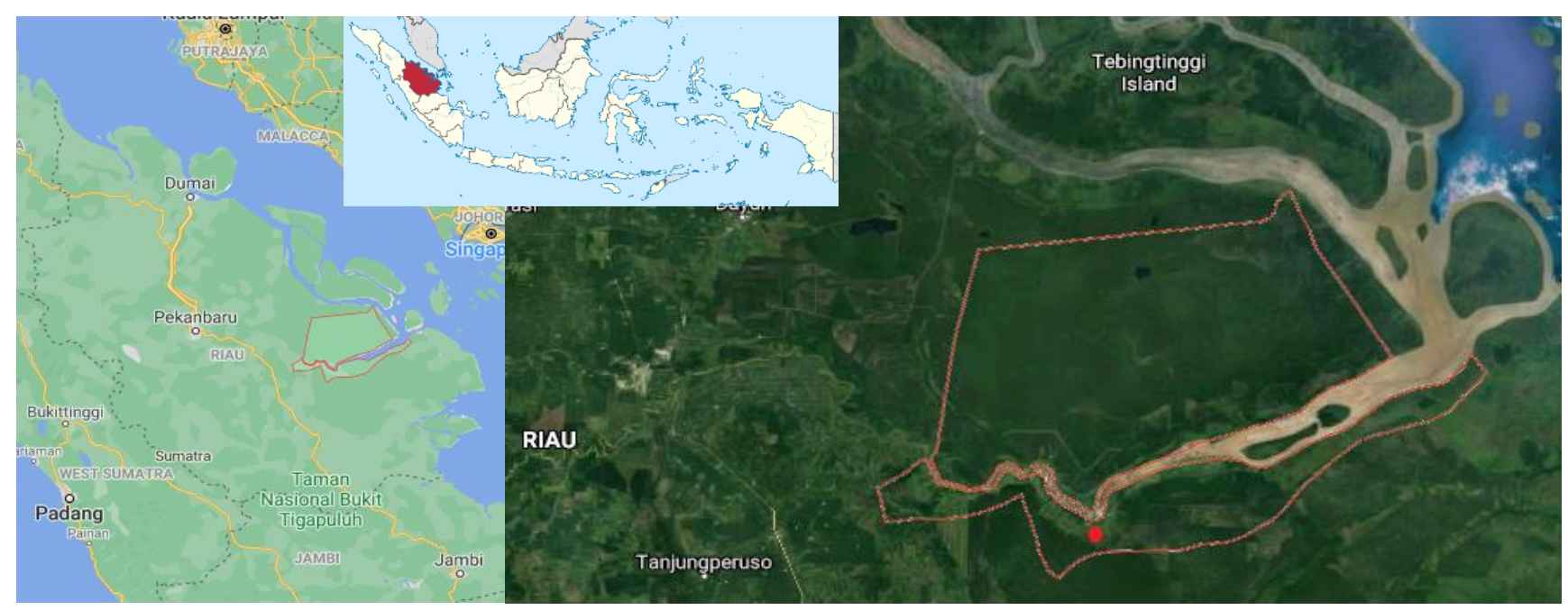

Figure 1. Study area of Teluk Meranti Sub-district, Pelalawan District, Riau Province, Indonesia 


\section{Vegetation analysis}

Field measurement was conducted in the burned area and adjacent unburned area by assuming both areas have similar vegetation conditions. Three transect lines were established in each area. For each transect line, sample plots were established, consisting of three $20 \times 20 \mathrm{~m}^{2}$ sized sample plots for trees. There were 18 nested sample plots in total for tree measurement and fire severity assessment. Tree density (D) and relative density (RD) were analyzed using the following formulas:

$\mathrm{D}=$ Total number of individual of the species/sample plot area

$\mathrm{RD}=($ Density of a given species/Total densities of all the species) $\times 100 \%$

\section{Soil condition}

Soil samples for chemical properties, bulk density, and burned peat depth were taken from each sample plot. There are 108 soil samples in total. Soil samples were analyzed at

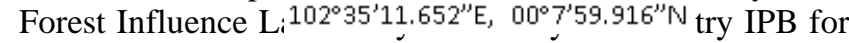
bulk density, soil pH, and CFC. At Laboratory of Fertilizer and Soil, Faculty of Agriculture analyzed C-organic and base cations of $\mathrm{Na}, \mathrm{Ca}, \mathrm{K}, \mathrm{Mg}$. For soil chemical properties, soil samples were taken using a small shovel of about $1 \mathrm{~kg}$ per hole. Soil ring was used to take soil samples in $0-10 \mathrm{~cm}$ depth for bulk density analyses. For measuring the burned depth, a hole sized 30 (width)x30 (length)x50 $\mathrm{cm}$ (height/depth) was constructed in burned plots and burned peat depth was measured using a tape from the soil surface until the edge of the charred layer observed. The burned peat depth was measured from the soil cross-section near the canal as well.

\section{Fire severity assessment}

Fire severity assessment was approached using the fire severity assessment method of Syaufina (2017). The assessment applied aggregate scoring of two criteria of vegetation condition (70\%) and soil condition (30\%).
Vegetation condition assessment is conducted by measuring and observing individual tree damage, stand damage, and vegetation biodiversity change, while soil condition criteria include physical properties, chemical properties, and peat burned depth.

\section{Data analysis}

Biodiversity analysis

Vegetation diversity condition using Shannon Index of General Diversity with the following formula:

$\mathrm{H}^{\prime}=-\Sigma_{\mathrm{i}=1}^{\mathrm{s}}[(\mathrm{ni} / \mathrm{N})] \ln [(\mathrm{ni} / \mathrm{N})]$

Where:

$H^{\prime}=$ Diversity Index of Shannon-Wiener, $s=$ species number

ni $=$ The i-th species density, $\mathrm{N}=$ Total density

Species Diversity Index of Shannon-Wienner (H') has three criteria, namely: $\mathrm{H}^{\prime}<2=$ low, $2<\mathrm{H}^{\prime}<3=$ moderate, and $\mathrm{H}^{\prime}>3=$ high.

\section{Fire severity assessment}

Fire severity was assessed by aggregate scoring of vegetation condition and soil condition (Syaufina 2017), as shown in Table 1. In the end, the fire severity level will be obtained from the aggregate vegetation and soil condition scores (Table 2).

Table 2 Scoring system of fire severity on the burned area

\begin{tabular}{ll}
\hline \multicolumn{1}{c}{ Fire severity level } & $\begin{array}{c}\text { Total score (Vegetation condition } \\
\text { score + Soil condition score) }\end{array}$ \\
\hline Very light & $0-20$ \\
Light & $>20-40$ \\
Moderate & $>40-60$ \\
High & $>60-80$ \\
Very high & $>80-100$ \\
\hline
\end{tabular}

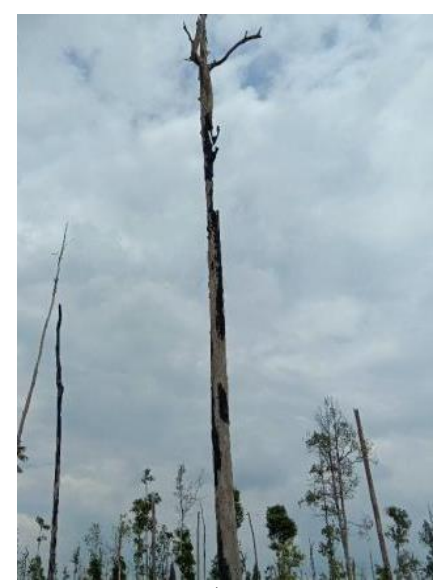

A

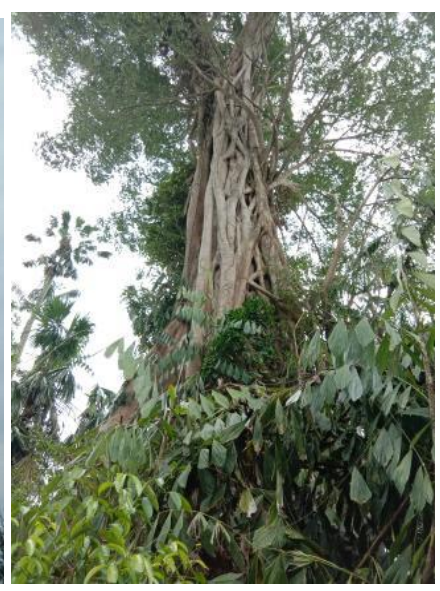

B

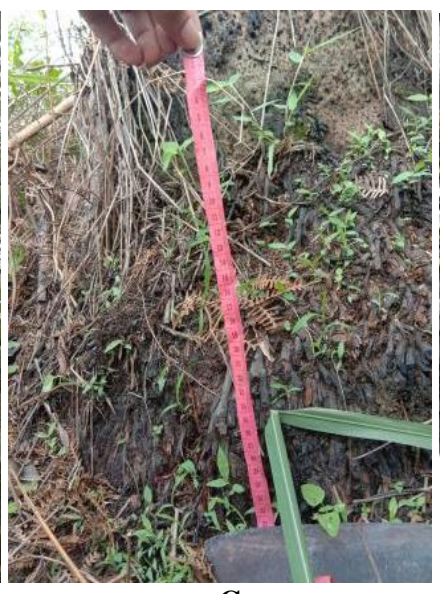

C

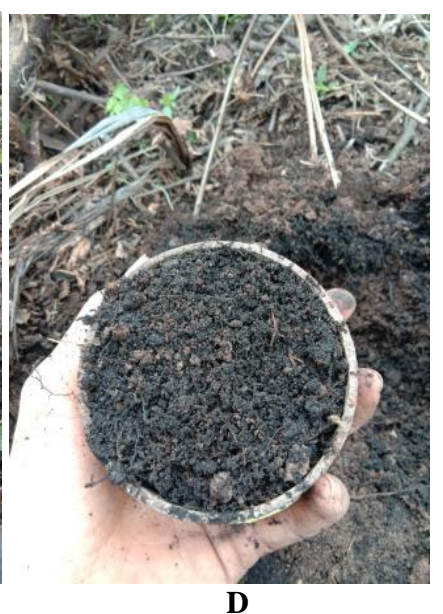

D

Figure 2. Study area condition (A. Burned area, B. Unburned area) and field measurement (C. Burned peat depth using diameter tape on soil cross-section, D. Soil sampling using soil ring for bulk density) 
Table 1. Parameter and weighted scoring for vegetation condition and soil condition

\begin{tabular}{lc}
\hline No. Parameter & $\begin{array}{c}\text { Weighted } \\
\text { score }\end{array}$ \\
\hline $\begin{array}{l}\text { A. Individual tree damage } 35 \% \\
\text { B. Burned vegetation severity level } \\
\quad \text { Percentage of dead trees and survival trees }\end{array}$ & $15 \%$ \\
$\begin{array}{l}\text { C. Vegetation diversity } \\
\text { Species composition change, species } \\
\text { diversity index, species evenness index, } \\
\quad \text { similarity index. }\end{array}$ & $20 \%$ \\
$\begin{array}{l}\text { D. Physical soil properties } \\
\text { Organic layer thickness, bulk density, }\end{array}$ & $8 \%$ \\
$\begin{array}{l}\text { E. Chemical soil properties } \\
\text { pH change, CFC, cation content }\end{array}$ & $10 \%$ \\
$\begin{array}{l}\text { F. Soil severity level } \\
\text { Burned depth }\end{array}$ & $12 \%$ \\
\hline
\end{tabular}

\section{RESULTS AND DISCUSSION}

\section{Tree species diversity}

Vegetation analyses show that 24 tree species were found in unburned plots, but only 2 tree species were found in burned plots (Table 3.). Among the 24 species in unburned plots, Intsia bijuga has the largest relative density $(15.11 \%)$ that is followed by Ochanostachys amentacea (12.2\%) and Shorea macroptera (11.04). It seems that Macaranga pruinosa and Shorea macroptera, the only found species in burned plots, are the most survived species with a relative density of 73.91 for $S$. macroptera and 26.09 for $M$. pruinosa. Both species had high adaptation to fire and may be used as post-fire rehabilitation species. After two months-fire, species density is significantly different by $86.6 \%$ from 0.05 individual/hectare to 0.006 individual/ha. In line with this figure, the diversity index has been significantly different as well by $80 \%$. Diversity index $\left(\mathrm{H}^{\prime}\right)$ of unburned plots of about 2.86 is categorized as moderate diversity, while that of burned plots of about 0.57 is categorized as low diversity. Therefore, the peatland fire in Teluk Meranti Village seems to lead to the loss of tree species diversity. According to previous findings, forest fire has significantly contributed to decreasing biodiversity, the number of individuals, and the number of plant species (Blackham et al. 2014, Agus et al. 2019). The frequent or severe fires affected the diversity of forest regrowth by its proximity to forest remnants, which are dominated by pioneer species, giving evidence that forest recovery is initiated (Lestari et al. 2021). Ten species were found in a highly degraded forest of West Kalimantan, e.g., Calophyllum inophyllum, Cyathocalyx biovulatus, Neoscortechinia kingii, and Eugenia cerina, were not present in low, degraded one (Astiani 2016).

On the other hand, the Evenness Index (Figure 3.) indicates a quite similar value of both unburned (0.90) and burned plots $(0,83)$. Although the diversity index is significantly different, the individuals in the community are distributed more equitably among these species. It is in line with Ludwig and Reynolds (1988) that if the Species Evenness Index (E) is close to 1 , species distribution is almost similar in each tree community. It seems that the burned plots investigated by this study are a secondary peat swamp forest indicated by lower diversity after fire disturbance compared to the primary forest that is higher in diversity after disturbance (Chang et al. 2019). The level of degradation may alter diversity in different magnitudes (Astiani 2016).

\section{Individual tree damage}

The first indicator for fire severity assessment is individual tree damage using several parameters, namely tree death, stem damage, crown damage, foliage damage, and roots damage. The study found that the whole 172 trees in unburned plots were still alive, while the trees in burned plots had only 6 trees survived, the other 17 trees $(73.9 \%)$ were dead. The ability of burned trees to survive is influenced by fire-adaptive traits, including buds, spores, lignotubers, sprouts (Syaufina and Ainuddin 2011), related to nutrient dynamics linked to plant metabolism. They can vary markedly among species, thus representing a key aspect of functional diversity (Chang et al. 2019).

Damage location can be defined as below stem part and below and upper stem part. Most trees have been damaged by fire in the below and upper parts (73.9\%). About $27.1 \%$ has been damaged at below part only. It is evident that fire in the study area can be classified into three types: ground fire, surface fire, and crown fire. The ground fire slowly consumes forest fuel in the rooting area underground. The surface fire burns below part stem and upper part stem, and lastly, the crown attacks crown and foliage parts.

Based on damage types, most of the trees had scorched stems (95.6\%), and only $4.4 \%$ had wound and scorched stems. Field observation did not find any biological attacks of pests and diseases on the damaged trees. Therefore, it shows that damage due to fire is more dominant compared to other damages caused. The heat from forest fire may reach above $1000{ }^{\circ} \mathrm{C}$, which causes severe damage to trees or even kill them directly. Scorched stem and wound are the symptoms of burning impacts. When the wound trees are survived, other forest disturbances such as pests and diseases may attack the trees, leading to permanently deformed trees. Hence, forest increment and forest function may disappear.

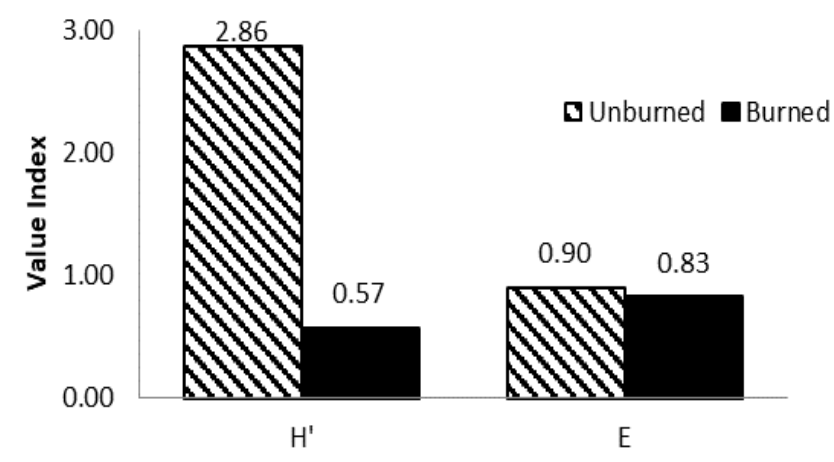

Figure 3. Differences of Diversity Index (H') and Evenness Index (E) in Unburned and Burned plots 
The second indicator for fire severity is vegetation burned severity, classified as low, moderate, and high, based on the percentage of burned dead trees and burned survived trees. Field observation and measurement revealed none of the undamaged trees, 17 burned dead trees $(73.91 \%)$, and only $6(26.09 \%)$ burned trees are still alive. Therefore, vegetation burned severity is categorized as high, and the weighted score is 15. Fire has some consequences on vegetation, including death of trees and destruction of natural regeneration, wounded trees, decreasing stand increment, damaged trees and decreasing wood quality, and disturbance of forest function. Peatland degradation due to fragmentation and repeated fires resulted in drastic changes to vegetation structure and led to biodiversity loss (Posa 2011, Dohong et al. 2017).

The third indicator is vegetation diversity, assessed by changes in the number of tree species, Species Diversity Index, Species Evenness Index, and Species Similarity Index. Field assessment indicates a decreasing number of trees from 16 to 2 species of Shorea macroptera and Macaranga pruinosa. The previous study of the high fire severity of Tesso Nilo National Park, Riau, found a similar trend of lowering the number of trees from 30 to 3 species after the fire (Syaufina et al. 2018). The two survived species found in this study are $S$. macroptera and $M$. pruinosa. Dipterocarp species of $S$. macroptera is a lowland dipterocarp forest species recognized as threatened by habitat loss due to logging and deforestation as per the Least Concern (LC) in IUCN Red List. M. pruinosa is known as a pioneer species with high survival growth ability in an open area. Meanwhile, the Species Diversity index is 0.57 or less than 1.5, Species Evenness Index is 0.83 , and Species Similarity Index is $0.19 \%$. Therefore, the weighted score for vegetation diversity is 9 . The low diversity index in burned areas shows that the forest community at the study site has low complexity or is arranged by a small number of species (only two species in this study). Sites suffering high and low-severity disturbance recovered more slowly in response to different mechanisms (seed/abiotic conditions versus light limitation, respectively). These findings indicate that rates of community change are driven not only by disturbance severity but also by the various mechanisms that mediate community dynamics (Chang et al. 2019). From a regional perspective, repeated fires have been the major threats in transforming peat swamp forests into degraded and fragmented landscapes, resulting in peatland ecosystem decline, biodiversity loss, and globally significant volumes of carbon emissions (Dohong et al. 2017).

Table 4 indicates the detailed scoring result for vegetation condition indicators and parameters. There are three indicators, namely: Individual tree damage, Burned vegetation severity, and Vegetation diversity. For individual tree damage, parameters of crown damage, foliage damage, and branch damage have high scores. Decreasing vegetation diversity has been observed obviously. In summary, the result of the assessment on fire severity for vegetation conditions indicates the total weighted score is 75 .

Table 3. Number, density, relative density, and diversity index of species found in unburned and burned plots

\begin{tabular}{|c|c|c|c|c|c|c|c|c|}
\hline \multirow{2}{*}{ Scientific name } & \multicolumn{4}{|c|}{ Unburned area } & \multicolumn{4}{|c|}{ Burned area } \\
\hline & $\mathbf{N}$ & D & RD & $\mathbf{H}^{\prime}$ & $\mathbf{N}$ & D & RD & $\mathbf{H}^{\prime}$ \\
\hline Alstonia scholaris & 2 & 0.0006 & 1.1628 & 0.0518 & 0 & & & \\
\hline Durio zibethinus & 3 & 0.0008 & 1.7442 & 0.0706 & 0 & & & \\
\hline Macaranga pruinosa & 8 & 0.0022 & 4.6512 & 0.1427 & 6 & 0.0017 & 26.0870 & 0.3505 \\
\hline Syzygium sp. & 12 & 0.0033 & 6.9767 & 0.1858 & 0 & & & \\
\hline Ixonanthes icosandra & 14 & 0.0039 & 8.1395 & 0.2042 & 0 & & & \\
\hline Syzygium subglauca & 3 & 0.0008 & 1.7442 & 0.0706 & 0 & & & \\
\hline Quercus argentata & 3 & 0.0008 & 1.7442 & 0.0706 & 0 & & & \\
\hline Shorea macroptera & 19 & 0.0053 & 11.0465 & 0.2434 & 17 & 0.0047 & 73.9130 & 0.2234 \\
\hline Calophyllum inophyllum & 4 & 0.0011 & 2.3256 & 0.0875 & 0 & & & \\
\hline Intsia bijuga & 26 & 0.0072 & 15.1163 & 0.2856 & 0 & & & \\
\hline Polyalthia cauliflora & 5 & 0.0014 & 2.9070 & 0.1029 & 0 & & & \\
\hline Nephelium lappaceum & 8 & 0.0022 & 4.6512 & 0.1427 & 0 & & & \\
\hline Shorea acuminata & 6 & 0.0017 & 3.4884 & 0.1171 & 0 & & & \\
\hline Koompassia malaccensis & 7 & 0.0019 & 4.0698 & 0.1303 & 0 & & & \\
\hline Shorea johorensis & 5 & 0.0014 & 2.9070 & 0.1029 & 0 & & & \\
\hline Garcinia parvifolia & 3 & 0.0008 & 1.7442 & 0.0706 & 0 & & & \\
\hline Ficus elastica & 3 & 0.0008 & 1.7442 & 0.0706 & 0 & & & \\
\hline Baccaurea deflexa & 3 & 0.0008 & 1.7442 & 0.0706 & 0 & & & \\
\hline Palaquium sericeum & 3 & 0.0008 & 1.7442 & 0.0706 & 0 & & & \\
\hline Syzygium cuminii & 4 & 0.0011 & 2.3256 & 0.0875 & 0 & & & \\
\hline Pentaspadon motleyii & 2 & 0.0006 & 1.1628 & 0.0518 & 0 & & & \\
\hline Diaphania costata & 4 & 0.0011 & 2.3256 & 0.0875 & 0 & & & \\
\hline Ochanostachys amentacea & 21 & 0.0058 & 12.2093 & 0.2568 & 0 & & & \\
\hline Archidendron jiringa & 4 & 0.0011 & 2.3256 & 0.0875 & 0 & & & \\
\hline Total & 172 & 0.0478 & 100 & 2.8619 & 23 & 0.0064 & 100 & 0.5740 \\
\hline
\end{tabular}


Table 4. Assessment result for vegetation condition in burned plots

\begin{tabular}{|c|c|c|c|c|c|c|}
\hline Indicator & Parameter & Condition & Score & Weight & $\begin{array}{c}\text { Field } \\
\text { measurement }\end{array}$ & $\begin{array}{c}\text { Weighted } \\
\text { score }\end{array}$ \\
\hline \multirow{27}{*}{$\begin{array}{l}\text { Individual } \\
\text { trees } \\
\text { damage }\end{array}$} & \multirow{2}{*}{ Tree death } & Dead trees & 1 & \multirow[t]{3}{*}{6} & 17 & 6 \\
\hline & & Living trees & 0 & & 6 & 0 \\
\hline & Stem damage & & & & & \\
\hline & \multirow[t]{3}{*}{ Burned part } & Below and upper part of stem burned & 2 & \multirow[t]{3}{*}{1} & 17 & 2 \\
\hline & & Below part of stem burned & 1 & & 6 & 1 \\
\hline & & Unburned stem & 0 & & 0 & 0 \\
\hline & \multirow[t]{4}{*}{ Damage types } & Scorched and wounded & 3 & \multirow[t]{4}{*}{1} & 1 & 3 \\
\hline & & Scorched & 2 & & 22 & 2 \\
\hline & & Wounded & 1 & & 0 & 1 \\
\hline & & Not scorched nor wounded & 0 & & 0 & 0 \\
\hline & \multirow[t]{4}{*}{ Crown damage } & $75-100 \%$ crown burned & 3 & \multirow[t]{4}{*}{2} & 16 & 6 \\
\hline & & $50 \%-<75 \%$ crown burned & 2 & & 3 & 4 \\
\hline & & $25 \%-<50 \%$ crown burned & 1 & & 4 & 2 \\
\hline & & $<25 \%$ crown burned & 0 & & 0 & 0 \\
\hline & \multirow[t]{4}{*}{ Branch damage } & Broken and burned & 3 & \multirow[t]{4}{*}{2} & 7 & 6 \\
\hline & & Burned & 2 & & 2 & 4 \\
\hline & & Broken & 1 & & 2 & 2 \\
\hline & & Not broken nor burned & 0 & & 2 & 0 \\
\hline & \multirow[t]{4}{*}{ Foliage damage } & $75-100 \%$ foliage burned & 3 & \multirow[t]{4}{*}{2} & 15 & 6 \\
\hline & & $50 \%-<75 \%$ foliage burned & 2 & & 4 & 4 \\
\hline & & $25-50 \%$ foliage burned & 1 & & 4 & 2 \\
\hline & & $<25 \%$ foliage burned & 0 & & 0 & 0 \\
\hline & \multirow{4}{*}{ Root damage } & Wounded and burned & 3 & \multirow[t]{5}{*}{2} & & \\
\hline & & Burned & 2 & & & \\
\hline & & Wounded & 1 & & & \\
\hline & & Not wounded nor burned & 0 & & & \\
\hline & \multicolumn{2}{|c|}{ Sub Total score for individual trees damage } & & & & 51 \\
\hline \multirow{4}{*}{$\begin{array}{l}\text { Burned } \\
\text { vegetation } \\
\text { severity }\end{array}$} & Low & $\begin{array}{l}\text { At least } 50 \% \text { of undamaged trees, } 80 \% \\
\text { of burned trees survive }\end{array}$ & 1 & \multirow[t]{4}{*}{5} & & \\
\hline & Moderate & $\begin{array}{l}20-50 \% \text { undamaged trees, } 40-80 \% \\
\text { burned trees survive }\end{array}$ & 2 & & & \\
\hline & High & $\begin{array}{l}\text { Less than } 20 \% \text { of undamaged trees, less } \\
\text { than } 40 \% \text { of burned trees survive }\end{array}$ & 3 & & $26.09 \%$ & 15 \\
\hline & \multicolumn{3}{|c|}{ Sub Total score for burned vegetation severity } & & & 15 \\
\hline \multirow[t]{14}{*}{$\begin{array}{l}\text { Vegetatio } \\
\text { n diversity }\end{array}$} & \multirow[t]{3}{*}{$\begin{array}{l}\text { Changes in species } \\
\text { composition }\end{array}$} & $\begin{array}{l}\text { Decreasing of number of commercial } \\
\text { tree species }\end{array}$ & 2 & \multirow[t]{3}{*}{2} & \multirow[t]{3}{*}{14} & 4 \\
\hline & & $\begin{array}{l}\text { No changes in number of commercial } \\
\text { tree species }\end{array}$ & 1 & & & \\
\hline & & $\begin{array}{l}\text { Increasing of number of commercial } \\
\text { tree species }\end{array}$ & 0 & & & \\
\hline & Species Diversity Index & $<1.5$ & 2 & 1 & 0.57 & 2 \\
\hline & & $1.5-3.5$ & 1 & & & \\
\hline & & $>3.5$ & 0 & & & \\
\hline & Species Evenness & 0 & 2 & 1 & 0.83 & 1 \\
\hline & Index & between 0 and 1 & 1 & & & \\
\hline & & 1 & 0 & & & \\
\hline & Similarity Index & 0 & 2 & 2 & $0.19 \%$ & 2 \\
\hline & & $<75 \%$ & 1 & & & \\
\hline & & $>75 \%$ & 0 & & & \\
\hline & Sub Total score for vege & tion diversity & & & & 9 \\
\hline & Total score for vegetatio & condition & & & & 75 \\
\hline
\end{tabular}

Survival of trees depends on several factors, including food storage of the plant, fire-adaptive traits, location, tree size, and crown damage. A study in Central Kalimantan found that some woody species could survive from fire by sprouting as stumps or roots (Blackham et al. 2014). The heat produced by a forest fire can sometimes reach above $1000^{\circ} \mathrm{C}$ and may kill trees directly. Lignin and cellulose are the main constituents of forest fuel that start to be degraded at the temperature of $130{ }^{\circ} \mathrm{C}$ to $190{ }^{\circ} \mathrm{C}$. In some cases, trees can survive with damages in certain parts. However, most trees in the study area have damages in the below and upper parts of the stem, meaning that ground fire and 
surface fire occurred. The surface fire seems to develop to the upper part of the trees creating crown fire, which is indicated by heavy crown damage and heavy foliage damage. The survived trees have various diameters, ranging from 28 to $45 \mathrm{~cm}$ in light to moderate burned sites. It increased with tree size $(\mathrm{dbh}>20 \mathrm{~cm})$ and decreased with crown damage and burned severity.

\section{Soil condition}

Peat soil has a relatively very high water holding capacity based on the dry weight. Maximum water holding capacity for fibric type is $580-3000 \%$, hemic type of 450 $850 \%$, and sapric type is $<450 \%$, respectively (Susandi et al. 2015). Based on the field test, peat decomposition type in the study area is sapric, which is the most decomposed peat as the origin peat is unrecognized, dark brown to black in color, and fiber content $<15 \%$ if squeezed.

The first indicator for soil condition assessment is physical soil properties, including organic layer and bulk density. Moisture content (Figure 4) in unburned plots ranged from 86.08 to $113.95 \%$, with an average of $100.21 \%$, whereas those of burned plots ranged from 41.94 to $99.74 \%$, with an average of $64.94 \%$. Decreasing moisture content after the fire was due to irreversible drying of the peat as a hydrophobic material (Agus et al. 2014), which appears when the water content passes over

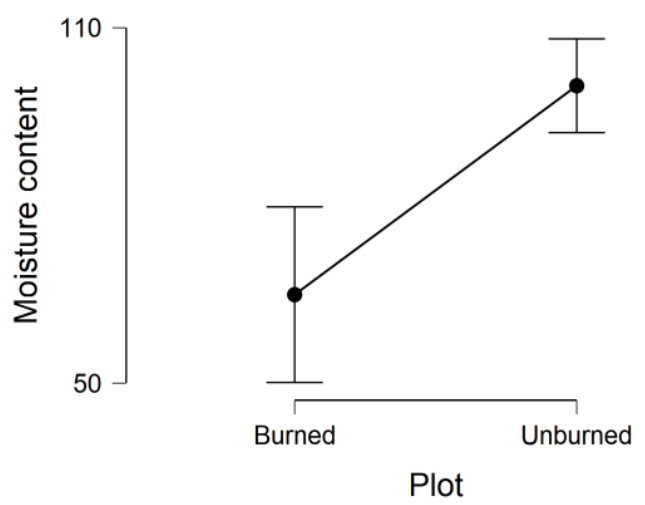

Figure 4. Mean moisture content of peat samples taken in burned and unburned plots

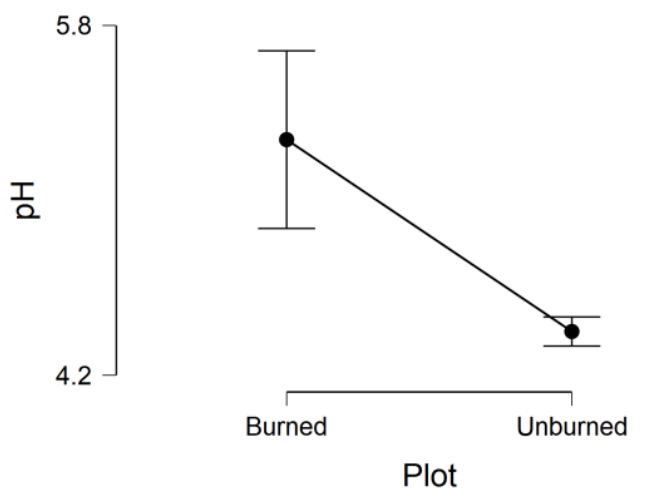

Figure 6. Mean $\mathrm{pH}$ of peat samples taken in burned and unburned plots the critical water content for the occurrence of hydrophobicity (Nugraha et al. 2016) and hence, it is relatively easy to burn during the dry season but flooded during the rainy season (Agus et al. 2019).

Bulk Density (BD) analyses show that there is increasing value after the fire. It ranged from 0.39 to 0.45 $\mathrm{g} / \mathrm{cm}^{3}$ with an average of $0.42 \mathrm{~g} / \mathrm{cm}^{3}$ in unburned plots and from 0.36 to $0.60 \mathrm{~g} / \mathrm{cm}^{3}$ with an average of $0.50 \mathrm{~g} / \mathrm{cm}^{3}$ burned plots (Figure 5). The heating process during a fire may increase soil temperature and destroy surface soil structure, soil pore space, increase bulk density (Murtinah et al. 2017), and decrease soil water level and moisture content. It leads to increase in bulk density (Ratnaningsih and Prasetyaningsih 2017). Besides, ash produced by the burning process may fill soil pores that can increase bulk density.

The second indicator for soil condition is chemical soil properties, including soil $\mathrm{pH}, \mathrm{C}$-organic content, cations $(\mathrm{Mg}, \mathrm{Ca}, \mathrm{K}, \mathrm{Na}$ ) contents. In general, peat soil has low fertility indicated by low $\mathrm{pH}$ (acidic), low macronutrient content $(\mathrm{Ca}, \mathrm{K}, \mathrm{Mg}, \mathrm{P})$, and micronutrient content $(\mathrm{Cu}, \mathrm{Zn}$, Mn, and B) (Agus et al. 2014). The study revealed that soil $\mathrm{pH}$ in unburned plots ranged from 4.2 to 4.5 with an average of 4.4 in unburned plots and from 5.1 to 5.5 with an average of 5.28 in burned plots (Figure 6).

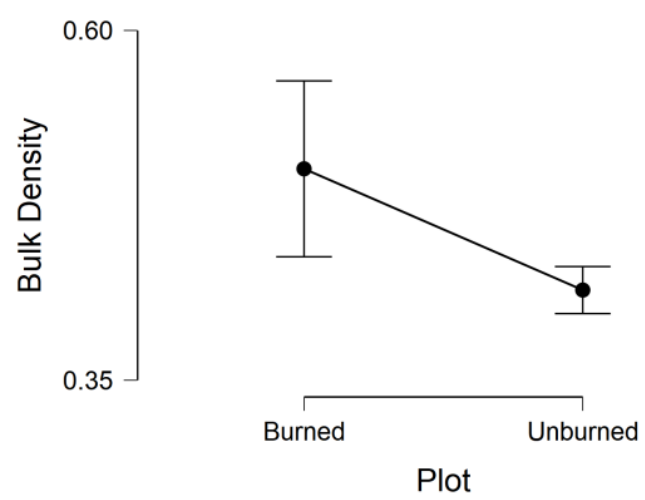

Figure 5. Mean bulk density of peat samples taken in burned and unburned plots

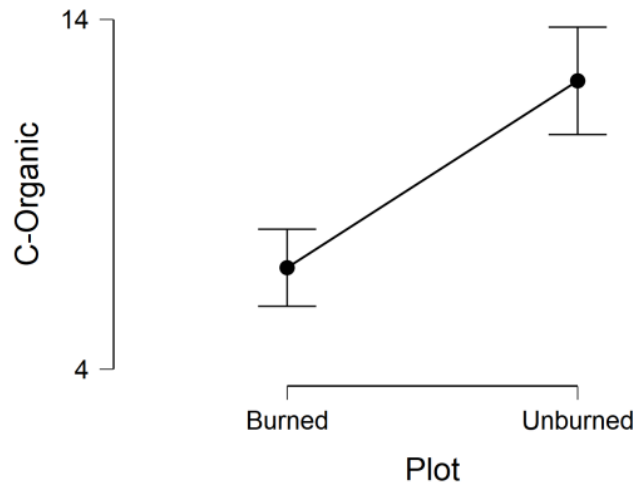

Figure 7. Mean C-organic content of peat samples taken in burned and unburned plots 

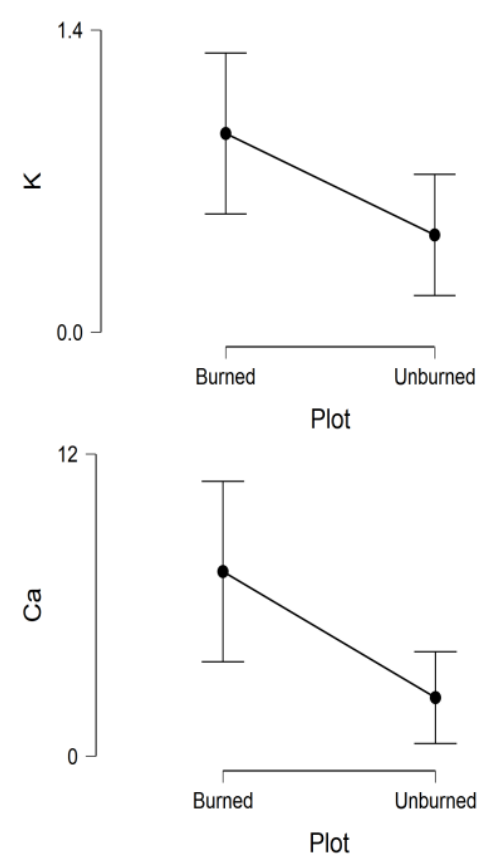
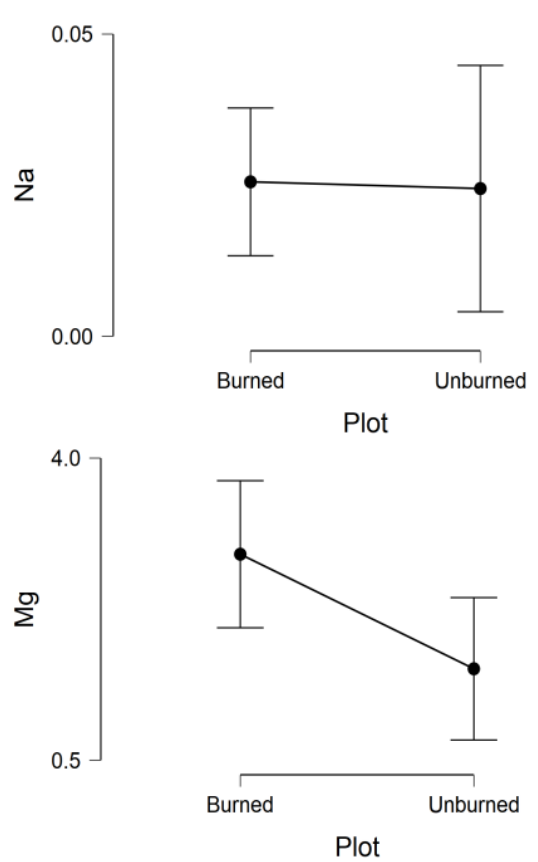

Figure 8. Mean cations content of peat samples taken in burned and unburned plots

The figures indicate that $\mathrm{pH}$ soil in both unburned and burned plots is acidic. Though, there is a higher $\mathrm{pH}$ value after fire by 1.20 . Ash produced by burning may increase $\mathrm{pH}$ as high temperature $\left(400-500{ }^{\circ} \mathrm{C}\right)$ may break down organic material of forest fuels and release the cations. A similar result is shown by another study in Pelalawan District, Riau, which found increasing $\mathrm{pH}$ at the burning area (Tata et al. 2018).

The C-organic content is a carbon content in the soil as organic material decomposition process products by living organism as the main component of soil organic materials, which is potential fuel in soil (ITPS 2017). The study shows that $\mathrm{C}$ organic content in unburned plots ranged from 10.70 to $14.40 \%$, with an average of $12.25 \%$, which is higher than that of burned plots ranged from 6.20 to $7.60 \%$ with an average of $6.90 \%$ (Figure 7). It seems that burning has significantly lowered C organic content by $43.00 \%$. Due to the loss of the crown of forest stand causes increase in throughfall and surface runoff leads to intensive leaching (Choiruddin et al. 2018). Forest fire types that occurred in the area of the crown fire, surface fire, and ground fire may cause lowering of $\mathrm{C}$ organic content.

Peat soil has high Cations Exchange Capacity (CEC) ranging from 50 to $100 \mathrm{cmol} / \mathrm{kg}$ but low base saturation. Nevertheless, the high CEC of peat soil does not explain high base cations content as peat soil is dominated by hydrogen ion (H+) (Agus et al. 2014). This study shows high CEC of burned peat soil samples after shaking the soil in a $600 \mathrm{ml}$ bottle of water and leaving them for deposition. The soil samples deposited for more than 24 hours are categorized as high CEC.

In line with $\mathrm{pH}$ value, base cations $(\mathrm{K}, \mathrm{Ca}, \mathrm{Mg}, \mathrm{Na})$ availability supplied from the ash in burned plots seems higher than those of unburned plots (Figure 8). Potassium content ranged from 0.20 to $0.70 \mathrm{cmol} / \mathrm{kg}$ with average of $0.50 \mathrm{cmol} / \mathrm{kg}$ in unburned plots and from 0.60 to 1.40 $\mathrm{cmol} / \mathrm{kg}$ with an average of $0.90 \mathrm{cmol} / \mathrm{kg}$ in burned plots. Calcium content in unburned plots ranged from 1.30 to $2.90 \mathrm{cmol} / \mathrm{kg}$ with an average of $2.30 \mathrm{cmol} / \mathrm{kg}$, and those of burned plots ranged from 5.20 to $11.20 \mathrm{cmol} / \mathrm{kg}$ with an average of $7.30 \mathrm{cmol} / \mathrm{kg}$. Magnesium content ranged from 1.20 to $2.50 \mathrm{cmol} / \mathrm{kg}$ with an average of $1.60 \mathrm{cmol} / \mathrm{kg}$ in unburned plots compared to those of burned plots ranged from 2.10 to $3.80 \mathrm{cmol} / \mathrm{kg}$ with an average of $2.90 \mathrm{cmol} / \mathrm{kg}$. In line with the previous cations, Sodium content is higher after the fire. It ranged from 0.01 to $0.04 \mathrm{cmol} / \mathrm{kg}$ with an average of $0.02 \mathrm{cmol} / \mathrm{kg}$ in unburned plots and from 0.02 to $0.03 \mathrm{cmol} / \mathrm{kg}$ with an average of $0.03 \mathrm{cmol} / \mathrm{kg}$ in burned plots. The accumulation of ashes in forest-peat-fires impacted area instantly increased $\mathrm{pH}$, organic matter, humic acid content, hydrophobicity, available-N, and available-K (Agus et al. 2019).

Independent t-Test (Table 5) suggested significant differences in moisture content (MC), bulk density (BD), $\mathrm{pH}$, C-organic content, Magnesium content, Calcium content, and Potassium content after burning. There is no difference between Sodium content in both unburned and burned plots. The burning process may alter soil properties $(\mathrm{pH})$ and soil fertility (ash content and P) (Tata et al. 2018).

Table 5. Independent t-Test of soil characteristics

\begin{tabular}{lccc}
\hline & $\mathbf{t}$ & $\mathbf{d f}$ & $\mathbf{p}$ \\
\hline $\mathrm{pH}$ & 4.916 & 16 & $<.001^{\mathrm{a}}$ \\
$\mathrm{C}-$ Organic & -6.521 & 16 & $<.001$ \\
$\mathrm{Mg}$ & 2.581 & 16 & 0.020 \\
$\mathrm{Ca}$ & 2.872 & 16 & 0.011 \\
$\mathrm{~K}$ & 2.323 & 16 & 0.034 \\
$\mathrm{Na}$ & 0.108 & 16 & 0.915 \\
$\mathrm{MC}$ & -4.840 & 16 & $<.001$ \\
$\mathrm{BD}$ & 3.072 & 16 & $0.007^{\mathrm{a}}$ \\
\hline
\end{tabular}

Note. Student's t-test. aLevene's test is significant $(\mathrm{p}<.05)$, suggesting a violation of the equal variance assumption 
Table 6. Indicator and parameters for soil condition assessment in burned plots

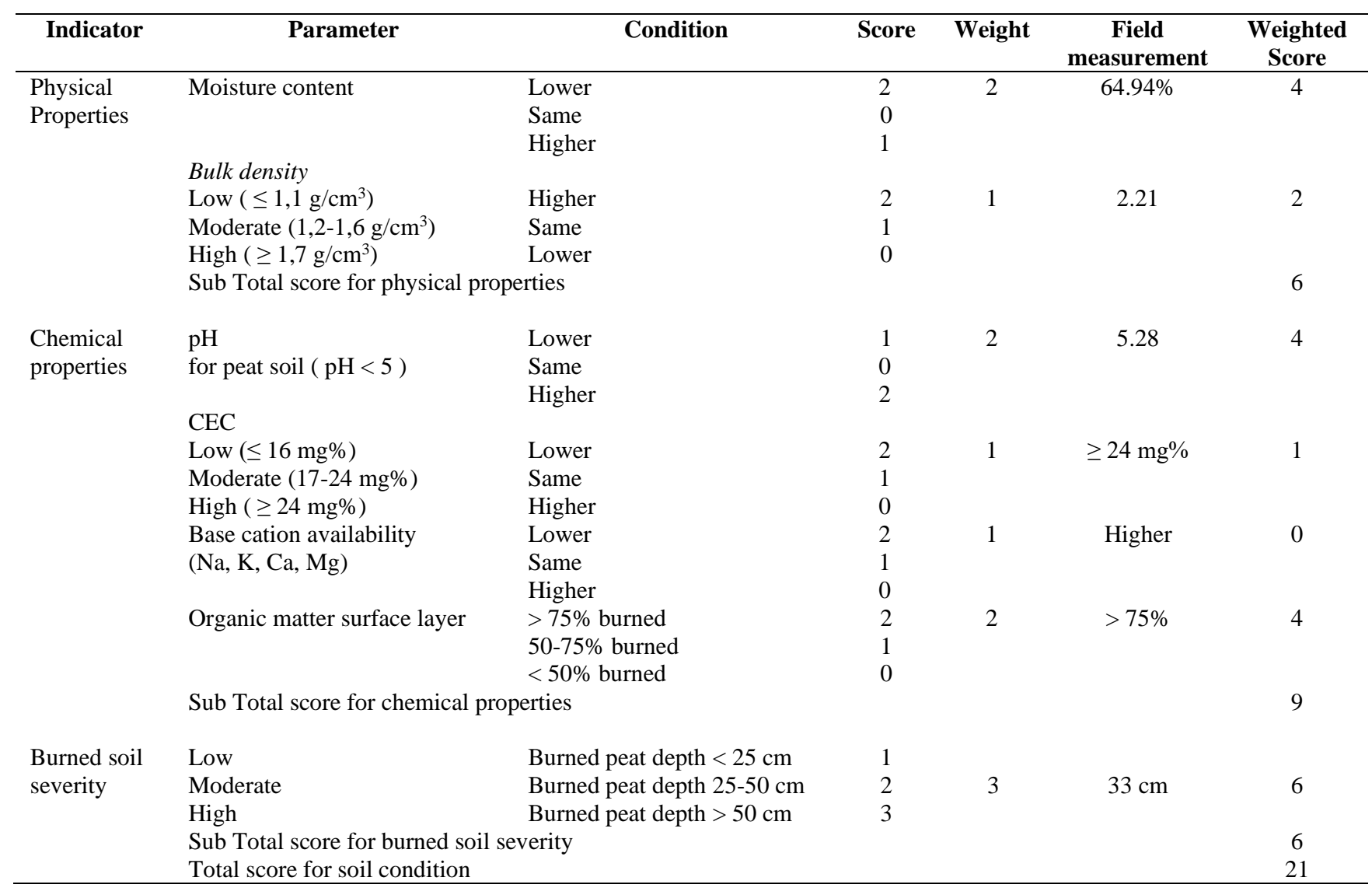

Tabel 7. Fire severity assessment result at Teluk Meranti, Pelalawan, Riau

\begin{tabular}{lccc}
\hline Criteria & Percentage & Score & Weighted score \\
\hline Vegetation & 70 & 75 & 52.50 \\
Soil & 30 & 21 & 6.30 \\
Total & & & 58.80 \\
\hline
\end{tabular}

The third indicator is burned peat depth as an essential component for peat fire severity assessment. Field observation and measurement resulted in an average burned peat depth of $33 \mathrm{~cm}$, which is classified as moderate severity. Severity assessment for soil condition criteria revealed that by using three indicators of physical soil properties, chemical soil properties, and burned soil severity (Table 6), soil condition in the burned area has an aggregate score of 21 . On soil, fire may alter physical, chemical, and biological properties during and after burning to negligible extent to very severe degree (Santín and Doerr 2016). Factors influencing the magnitude of the impacts include the original soil properties, fire intensity, fire severity, and post-fire precipitation.

In summary, the fire severity assessment in the study area has a total score of $58.80 \%$ based on two criteria of vegetation and soil condition (Table 7). The range of 40-
$60 \%$ indicates the forest fire that occurred at Teluk Meranti, Pelalawan, Riau had moderate fire severity.

The study suggested that forest fire that occurred at Teluk Meranti, Pelalawan, Riau has altered tree species diversity significantly. Species density in burned plots of 0.006 individual/ha is significantly lowered by $86.6 \%$ compared to that of unburned plots of 0.05 individual/ha, and so diversity index has significant difference by $80.00 \%$ of moderate diversity in unburned plots to low diversity in burned plots. Only two tree species survived in the burned plots, namely: $M$. pruinosa and $S$. macroptera. The first is endemic intolerant species to peat swamp forest, and the latter is typical dipterocarp lowland forest that has been included in IUCN Red List as Least Concern species. It seems that both species have fire-adaptive traits to survive from fire. Based on fire severity assessment using two criteria of vegetation and soil condition and severity indicators, including individual tree damage, burned vegetation severity, vegetation diversity, physical soil properties, chemical soil properties, and burned peat depth, forest fire occurred in the study area is considered having moderate fire severity.

\section{ACKNOWLEDGEMENTS}

The authors wish to thank Laboratory of Forest and Land Fires and Laboratory of Forest Influence of 
Department of Silviculture, Faculty of Forestry and Environment, IPB University, Laboratory of Soil Science of Faculty of Agriculture, IPB University, Mr. Ferdian Krisnanto, Head of BBPPIKHL-Sumatera Region and staffs, and all field assistants at Teluk Meranti Village, Pelalawan, Riau, and Dr. Anita Zaitunah for their invaluable support to this study.

\section{REFERENCES}

Agus F, Anda M, Jamil A, Masganti. 2014. Lahan Gambut Indonesia Pembentukan, Karakteristik, dan Potensi Mendukung Ketahanan Pangan Edisi Revisi. Badan Penelitian dan Pengembangan Pertanian Kementerian Pertanian. Jakarta. [Indonesian]

Agus C, Azmi FF, Ilfana ZR, Wulandari D, Rachmanadi D, Harun MK, Yuwati TW. 2019. The impact of forest fire on the biodiversity and the soil characteristics of tropical peatland. In: Handbook of Climate Change and Biodiversity. Springer, Cham. DOI: 10.1007/978-3-31998681-4 18

Astiani D. 2016. Tropical peatland tree species diversity altered by forest degradation. Biodiversitas 17 (1): 102-109. DOI 10.13057/biodiv/d170115.

Blackham GV, Webb EL, Corlett RT. 2014. Natural regeneration in a degraded tropical peatland, Central Kalimantan, Indonesia: Implications for forest restoration. For Ecol Manag 324, 8-15. DOI: 10.1016/j.foreco.2014.03.041.

Chang CC, Turner BL. 2019. Ecological succession in a changing world. J Ecol 107: 503-509. DOI: 10.1111/1365-2745.13132.

Choiruddin I, Donantho D, Hartanto RM. 2018. Pengaruh kebakaran lahan terhadap beberapa sifat kimia tanah ( $\mathrm{pH}, \mathrm{C}$-Organik, $\mathrm{N}, \mathrm{P}$, dan $\mathrm{K})$. Jurnal Agroekoteknologi Tropika Lembab 1: 11-15. [Indonesian]

Dohong A, Azis AA, Dargusch P. 2017. A review of the drivers of tropical peatland degradation in South-East Asia. Land Use Policy 69: 349-360. DOI: 10.1016/j.landusepol.2017.09.035.

Gray A, Davies GM, Domènech R, Taylor E, Levy PE, 2021. Peatland wildfire severity and post-fire gaseous carbon fluxes. Ecosystems 24: 713-725. DOI: 10.1007/s10021-020-00545-0.

Harrison ME. 2013. Using conceptual models to understand ecosystem function and impacts of human activities in tropical peat-swamp forests. Wetlands 33 (2): 257-267. DOI: 10.1007/s13157-013-0378-0.

Harrison ME, Ripoll Capilla B, Thornton SA. Cattau ME, Page SE. 2016. Impacts of the 2015 fire season on peat-swamp forest biodiversity in Indonesian Borneo. In: Peatlands in Harmony-Agriculture, Industry \& Nature, Proceedings of the 15th International Peat Congress: Oral Presentations, International Peatland Society, Jyväskylä/Kuching, 713-717.

Harrison ME, Rieley JO. 2018. Tropical peatland biodiversity and conservation in Southeast Asia. Foreword Mires Peat 22: 1-7. DOI: 10.19189/MaP.2018.OMB.382

Husson SJ, Limin SH, Boyd NS, Brousseau JJ, Collier S, Cheyne SM, D'Arcy LJ, Dow RA, Schreven S. 2018. Biodiversity of the Sebangau tropical peat swamp forest, Indonesian Borneo. Mires Peat 22: 1-50. DOI: 10.19189/MaP.2018.OMB.352.

Hoscilo A, Page SE, Tansey KJ, Rieley JO. 2011. Effect of repeated fires on land-cover change on peatland in southern Central Kalimantan, Indonesia, from 1973 to 2005. Intl J Wildland Fire 20 (4): 578-588. DOI: $10.1071 / \mathrm{WF} 10029$.

Ishihara MI, Firdaus R, Nakagoshi N. 2017. Peatland fires in Riau, Indonesia, in relation to land cover type, land management, landholder, and spatial management. J Environ Prot 8 (11): 1312. DOI: $10.4236 /$ jep.2017.811081

Intergovernmental Technical Panel of Soils [ITPS]. 2017. Global Soil Organic Carbon Map. Food and Agricultural Organization of United Nations, Rome.

Kiely L, Spracklen DV, Wiedinmyer C, Conibear L, Reddington CL, Nicholls SA, Lowe D, Arnold SR, Knote C, Khan F, Latif MT, Kuwata M, Budisulistiorini SH, Syaufina L. 2019. New estimate of particulate emissions from Indonesian peat fires in 2015. Atmos Chem Phys 19 (17): 11105-11121. DOI: 10.5194/acp-19-11105-2019.
Lembaga Penerbangan dan Antariksa Nasional [LAPAN]. 2016. Informasi Titik Panas (Hotspot) Kebakaran Hutan/Lahan. Pusat Pemanfaatan Penginderaan Jauh, Deputi Bidang Penginderaan Jauh, LAPAN, Jakarta. [Indonesian]

Lembaga Penerbangan dan Antariksa Nasional [LAPAN]. 2019. Sebaran Titik Panas di Provinsi Riau, LAPAN, Jakarta. www.modis-cataloglapan.go.id. [Indonesian]

Lee BPY, Davies ZG, Struebig MJ. 2017. Smoke pollution disrupted biodiversity during the $2015 \mathrm{El}$ Niño fires in Southeast Asia. Environ Res Lett 12 (9): 094022. DOI: 10.1088/1748-9326/aa87ed.

Lestari DP, Darusman T, Harsanto F, Arriyadi D, Ginanjar G. 2021. Understanding natural regeneration in burned tropical peatland: a strategy to accelerate the forest recovery process. Biotropia. DOI: 10.11598/btb.0.0.0.1330.

Lilleskov E, McCullough K, Hergoualc'h K, del Castillo Torres D, Chimner R, Murdiyarso D, Kolka R, Bourgeau-Chavez L, Hribljan J, del Aguila Pasquel J, Wayson C. 2019. Is Indonesian peatland loss a cautionary tale for Peru? A two-country comparison of the magnitude and causes of tropical peatland degradation. Mitigation Adapt Strategies Glob Change 24 (4): 591-623. DOI:10.17528/cifor/007490.

Ludwig JA, Reynolds JF. 1988. Statistical Ecology: A Primer on Methods and Computing. John Wiley \& Sons, New York.

MoEF 2018. Managing peatlands to cope with climate change: Indonesia's experience. Ministry of Environment and Forestry, Jakarta, Indonesia. [Indonesian]

Murtinah V, Edwin M, Bane O. 2017. Dampak kebakaran hutan terhadap sifat fisik dan kimia tanah di Taman Nasional Kutai, Kalimantan Timur. Jurnal Pertanian Terpadu 5 (2): 128-137. DOI: 10.36084/jpt..v5i2.133.

Nugraha MI, Annisa W, Syaufina L, Anwar S. 2016. Capillary water rises in peat soil as affected by various groundwater levels. Indonesian $\mathrm{J}$ Agric Sci 17 (2): 75-83. DOI: 10.21082/ijas.v17n2.2016.p75-83.

Page SE, Rieley JO, Banks CJ. 2011. Global and regional importance of the tropical peatland carbon pool. Glob Change Biol 17 (2): 798-818. DOI: $10.1111 /$ j.1365-2486.2010.02279.x

Page SE, Rieley JO, Hoscilo A, Spessa A, Weber U. 2013. Current fire regimes, impacts and the likely changes-IV: tropical Southeast Asia.

www.forestrybooks.com.

Page SE, Hooijer A. 2016. In the line of fire: the peatlands of Southeast Asia. Phil Trans R Soc B: Biol Sci 371 (1696): 20150176. DOI: 10.1098/rstb.2015.0176.

Posa MRC. 2011. Peat swamp forest avifauna of Central Kalimantan, Indonesia: Effects of habitat loss and degradation. Biol Conserv 144 (10): 2548-2556. DOI: 10.1016/j.biocon.2011.07.015.

Ratnaningsih AT, Prasetyaningsih SR. 2017. Dampak kebakaran hutan gambut terhadap subsidensi di Hutan Tanaman Industri. Jurnal Kehutanan Wahana Foresta 12 (1): 37-43. DOI: 10.31849/foresta.v12i1.200. [Indonesian]

Rohadi D, Herawati T, Rahmat M, Winarno B, Suwarno E. 2018. Penghidupan Berkelanjutan Bebas Polusi Asap. FORDA Press. Bogor. [Indonesian]

Santín C, Doerr S. 2016. Fire effects on soils: The human dimension. Philos Trans: Biol Sci 371 (1696): 1-10. DOI: 10.1098/rstb.2015.0171.

Susandi S, Oksana O, Arminudin AT. 2015. Analisis sifat fisika tanah gambut pada hutan gambut di Kecamatan Tambang Kabupaten Kampar Provinsi Riau. Jurnal Agroteknologi 5 (2): 23-28. DOI: 10.24014/ja.v5i2.1351. [Indonesian].

Syaufina L, Ainuddin AN. 2011. Impacts of fire on South East Asia tropical forest biodiversity: a review. Asian J Plants Sci 10 (4): 238244.

Syaufina L. 2017. Metode Penilaian Areal Pasca Kebakaran Hutan. IPB Press, Bogor. [Indonesian]

Syaufina L, Darojat SN, Sitanggang IS, Apriliantono. 2018. Forest fire as a threat for biodiversity and urban pollution. IOP Conf Ser: Earth Environ Sci 203 (1): 012015. DOI: 10.1088/17551315/203/1/012015.

Tata HL, Narendra BH, Mawazin M. 2018. Forest and land fires in Pelalawan District, Riau, Indonesia: Drivers, pressures, impacts and $\begin{array}{lllll}\text { responses. Biodiversitas } 19 & \text { (2): 494-501. DOI: }\end{array}$ 10.13057/biodiv/d190224

Turetsky MR, Benscoter B, Page S, Rein G, Van Der Werf GR, Watts A. 2015. Global vulnerability of peatlands to fire and carbon loss. Nat Geosci 8 (1): 11-14. DOI: 10.1038/NGEO2325. 